\title{
Efektivitas Pemberian Beberapa Dosis Kompos Kulit Bawang Merah Terhadap Serapan Hara Pada Polikultur Selada Dan Terung
}

\author{
Luluk Syahr Banu dan Siti M. Sholihah \\ Program Studi Agroteknologi Fakultas Pertanian Universitas Respati Indonesia \\ Email: luluksyahrbanu@gmail.com
}

\begin{abstract}
Abstrak
Limbah kulit bawang merah sangat melimpah. Adanya beberapa zat dan senyawa yang terdapat pada kulit bawang merah bisa memberikan kesuburan sehingga dapat mempercepat pertumbuhan buah dan bunga pada tanaman. Terung dan selada juga termasuk dalam tanaman yang bernilai ekonomis tinggi serta berpotensi dibudidayakan secara poliktur. Namun, banyak permasalahan dalam pertumbuhan terutama dalam penyerapan hara. Tujuan Penelitian iniadalah mengetahui pengaruh dosis kompos kompos kulit bawang merah yang efektif bagi pertumbuhan dan serapan hara oleh tanaman terung dan selada secara polikultur. Rancangan yang digunakan pada percobaan ini adalah Rancangan Acak Kelompok dengan lima taraf perlakuan yang terdiri dari dosis kompos kulit bawang merah dengan tanah terdiri atas $0 \mathrm{gr} / \mathrm{plibag}, 400 \mathrm{gr} / \mathrm{polibag}, 600$ gr/polibag, $800 \mathrm{gr} /$ polibag dan $1000 \mathrm{gr} /$ polibag dengan 5 ulangan pada tanaman selada dan terung. Variabel Pengamatan adalah tinggi tanaman dan jumlah daun tanaman serta analisisi kimia kompos kulit bawang merah. Hasil Penelitian menunjukkan beberapa dosis kompos kulit bawang merah tidak berpengaruh nyata bagi pertumbuhan tinggi tanaman terung, tinggi tanaman selada dan jumlah daun tanaman terung pada seluruh umur tanaman. Beberapa dosis kompos kompos kulit bawang merah berpengaruh nyata bagi pertumbuhan jumlah daun pada umur 21 dan 28 HST secara polikultur.
\end{abstract}

Kata kunci : kompos kulit bawang merah, terung, selada, polikultur

\section{Abstract}

Onion skin waste is very abundant. The presence of several substances and compounds contained in the skin of shallots can provide fertility so that it can accelerate the growth of fruit and flowers on plants. Eggplant and lettuce are also included in plants that have high economic value and have the potential to be cultivated in polyculture. However, there are many problems in growth, especially in nutrient absorption. The purpose of this study was to determine the effect of effective dose of onion peel compost on growth and nutrient uptake by eggplant and lettuce plants in polyculture. The design used in this experiment was a randomized block design with five levels of treatment consisting of a dose of onion peel compost with soil consisting of 0 gr/plibag, $400 \mathrm{gr} /$ polybag, $600 \mathrm{gr} /$ polybag, $800 \mathrm{gr} /$ polybag and $1000 \mathrm{gr} /$ polybag. with 5 replications on lettuce and eggplant. Observation variables were plant height and number of leaves and chemical analysis of onion peel compost. The results showed that several doses of onion peel compost had no significant effect on the growth of eggplant plant height, lettuce plant height and eggplant leaf number at all plant ages. Several doses of onion peel compost had a 


\section{Jurnal IImiah Respati}

significant effect on the growth of the number of leaves at the age of 21 and 28 DAP in polyculture.

Keywords: onion peel compost, eggplant, lettuce, polyculture

\section{PENDAHULUAN}

Bawang merah merupakan salah satu tanaman hortikultura yang mempunyai nilai ekonomis yang tinggi. Dalam kurun waktu beberapa tahun terakhir pasokan bawang merah melimpah. Jumlah kebutuhan nasional diperkirakan 165 ribu ton, sementara ketersediaan nasional ditaksir mencapai 190 ribu ton [1]. Surplus produk bawang merah juga memiliki dampak lain yaitu meningkatnya limbah kulit bawang merah yang sangat banyak.

Di wilayah Kramatjati saja rata-rata sampah organik yang dihasilkan dari aktivitas perdagangan sayur mayur, buah-buahan dan umbi-umbian sebanyak $3.778,97$ ton/hari dan sampah sayuran menempati $25 \%$ dari $90 \%$ komponen total sampah yang ada [2]. Sampah tersebut terutama sampah sayuran yang disebabkan dari sisa-sisa pembuangan kulit buah dan sayur. Salah satunya adalah bawang merah yang dapat menyebabkan pencemaran lingkungan apabila tidak dikelola dengan baik. Sampah tersebut terutama dari pembuangan kulit bawang merah dapat menyebabkan pencemaran lingkungan apabila tidak dikelola dengan baik. Selain itu sampah yang menumpuk ini dan tidak segera terangkut bisa menyebabkan sumber bau yang tidak sedap dan dapat memberikan efek buruk bagi lingkungan. Sampah kulit bawang merah yang umumnya dibuang ini dapat diberdayakan sebagai kompos. Selain itu minyak atsiri dari tanaman ini diketahui mengandung senyawa aktif yang dapat digunakan sebagai pengendali hama. Itulah yang membedakan kompos dari kulit bawang merah ini dengan kompos lainnya. Dalam sistem budidaya, diperlukan tambahan pupuk organik atau kompos sebagai penunjang pertumbuhan tanaman. Namun penggunaan limbah kulit bawang merah masih belum memberikan segi efisiensi dan praktis oleh petani pada umumnya sehingga dosis yang tepat sangat membantu untuk peningkatan pertumbuhan tanaman budidaya dan pengaplikasiannya pada beberapa jenis tanaman akan membantu merumuskan formulasi tepat penggunaan kompos limbah ini.Kebutuhan bawang merah untuk Jabodetabek berkisar 8.000 ton/bulan [1]. Bagian terluar dari umbi bawang merah ini berisi cadangan makanan yang mengandung flavonol $3,82 \mathrm{mg} / \mathrm{kg}$ dari golongan flavonoid yang memiliki aktivitas antioksidan [3]. Sampah kulit bawang merah ini juga sudah banyak dimanfaatkan di daerah Jakarta Timur sebagai campuran pupuk dan berhasil membuat tanaman tumbuh lebih optimal.Adanya beberapa zat dan senyawa 
yang terdapat pada kulit bawang merah bisa memberikan kesuburan sehingga dapat mempercepat pertumbuhan buah dan bunga pada tanaman. Limbah kulit bawang merah ini didapatkan dari pedagang bawang merah di pasar Kramat Jati yang sudah terlebih dahulu memanfaatkan sebagai sebagai kompos namun belum mengetahui hasil komposisi yang terkandung dalam limbah tersebut. Selain itu, penelitian pengaruh kompos kulit bawang merah dan NPK yang dilakukan oleh Yolanda et al (2019) menunjukkan hasil yang optimal dalam beberapa parameter pertumbuhan cabai [4].

Terung dan selada merupakan sayuran yang banyak dikonsumsi untuk meningkatkan gizi. Dalam sistem tumpang sari selada dan terung dapat tumbuh dengan optimal sehingga bisa dipadukan untuk polikultur [5]. Kedua tanaman sayuran ini dapat dilakukan dengan cara tumpang sari dan polikultur. Penanaman Polikultur juga dapat menjadi alternatif untuk solusi lahan sempit dengan tetap menjaga pertumbuhan tetap maksimal. Sistem ini meniru keanekaragaman ekosistem alami dan menghindari monokultur yang banyak juga masalahnya. Polikultur merupakan metode dalam pola penanaman lebih dari satu jenis [6]. Untuk daerah seperti di Jakarta sangat cocok digunakan karena curah hujan yang tidak merata dan sistem irigasi terbatas selain pada permasalahan lahan sempit. Banyak kelebihan polikultur yang lain yaitu meningkatkan kesuburan apabila menggunakan tanaman yang bersimbiosis dengan bakteri nitrogen, efisiensi penggunaan lahan dan mendapat panen beragam [6]. Jenis polikultur yang digunakan dalam penelitian ini adalah tanaman bersisipan dalam polibag dengan harapan produksi dan pertumbuhan kedua tanaman terung dan selada tersebut bisa optimal dengan menggunakan kompos berbahan dasar kulit bawang merah. Tujuan dari penelitian ini adalah mengetahui pengaruh dosis kompos kompos kulit bawang merah yang efektif bagi pertumbuhan dan serapan hara oleh tanaman terung dan selada secara polikultur.

\section{METODE PENELITIAN}

Pelaksanaan kegiatan penelitian ini dilakukan di Komplek Griya Mega Kampung Tengah pada bulan Agustus 2020 sampai dengan Maret 2021. Bahan yang diperlukan dalam penelitian adalah adalah benih selada dan terung, tanah, kompos kulit bawang merah, dan sekam.

Rancangan yang digunakan pada
percobaan ini adalah Rancangan Acak
Kelompok dengan lima taraf perlakuan yang
terdiri dari dosis kompos kulit bawang merah
dengan tanah dengan perbandingan 0 gr/plibag, 400 gr/polibag, 600 gr/polibag, 800gr/polibag dan $1000 \mathrm{gr} /$ polibag dan 5 ulangan pada masing-masing jenis tanaman . Tanaman selada dan terung disemai terlebih dahulu dengan menggunakan sekam dan tanah, setelah 2 minggu dipindahkan ke 
polibag dengan perbandingan media sesuai perlakuan. Analisis serapan hara dilakukan pada akar tanaman setelah panen. Panen tanaman terung dilakukan pada saat umur tanaman mencapai $120-125 \mathrm{hr}$ setelah tanam dan selada 45 - 60 hari setelah tanam.

Variabel penelitian ini adalah tinggi tanaman dan jumlah daun masing-masing tanaman. Tinggi tanaman diukur dengan menggunakan mistar setiap satu minggu sekali, Dimulai dari 7 HST, 14 HST, 21, 28, 35 HST untuk tanaman selada dan dimulai sejak 21 HST untuk tanaman terung diteruskan hingga 48 HST untuk terung. Jumlah daun pertanaman dihitung sejak dimulai dari 7 HST, 14 HST, 21, 28, 35 HST untuk tanaman selada dan dimulai sejak 21 HST untuk tanaman terungditeruskan hingga 48 HST untuk terung. Daun yang dihitung adalah daun yang telah terbentuk sempurna. Data yang diperoleh dari hasil penelitian kemudian ditabulasi dan dianalisis menggunakan Analisis Ragam
(ANOVA) dan dilanjutkan dengan uji BNT 5\% apabila berbeda nyata.

\section{PEMBAHASAN}

\section{Efektivitas Pemberian Beberapa Dosis}

Kompos Kulit Bawang Merah terhadap

Tinggi Tanaman Terung

Pengamatan tinggi tanaman terung dilakukan 5 kali yaitu 21 HST, 28 HST, 35 HST, 42 HST, dan 49 HST.Data hasil pengamatan dianalisis menggunakan uji $F$ dan untuk mengetahui perbedaan antar perlakuan maka dilakukan uji BNT yang hasilnya sebagaimana tertera pada Tabel 1. Dapat kita lihat pada Tabel 1 bahwa terjadi peningkatan yang signifikan terhadap pertumbuhan tinggi tanaman pada setiap dosis pupuk kompos kulit bawang merah yang digunakan. Namun, analisis anova menunjukkan tidak ada pengaruh nyata perlakuan kompos kulit bawang merah terhadap pertumbuhan tanaman terung.

Tabel 1. Rekapitulasi hasil uji BNT Efektivitas Pemberian Beberapa Dosis Kompos Kulit Bawang Merah terhadap tinggi tanaman terung

\begin{tabular}{cccccc}
\hline Perlakuan & \multicolumn{5}{c}{ Rata-rata tinggi tanaman $(\mathrm{cm})$} \\
\cline { 2 - 6 } & $21 \mathrm{HST}$ & $28 \mathrm{HST}$ & $35 \mathrm{HST}$ & 42 HST & 49 HST \\
\hline B0 & 7,44 & 7,44 & 10,90 & 11,56 & 18,90 \\
B1 & 9,20 & 9,20 & 13,90 & 14,86 & 24,70 \\
B2 & 8,70 & 8,70 & 14,30 & 16,20 & 25,40 \\
B3 & 9,36 & 9,40 & 13,24 & 14,70 & 28,50 \\
B4 & 8,10 & 8,70 & 11,40 & 12,28 & 25,40 \\
\hline
\end{tabular}

Keterangan : $\mathrm{B} 0=$ tanpa kompos kulit bawang merah, $\mathrm{B} 1=200 \mathrm{gram} /$ polibag, $\mathrm{B} 2=400$ gram/polibag, $B 3=800$ gram/polibag, dan B4=1000 gram/polibag. Angka yang diikuti notasi huruf yang sama menunjukkan berbeda tidak nyata.

Dari daftar sidik ragam menunjukkan bahwa perlakuan dengan dosis kompos kulit bawang merah berpengaruh tidak nyata terhadap tinggi tanaman pada semua umur 
pengamatan.Pertambahan tinggi tanaman diakibatkan terbentuknya sel-sel yang terbentuk di daerah meristem apikal dan berarti aktifitas pembelahan dan pemanjangan sel di pucuk merupakan inti dari pertumbuhan tinggi tanaman, kelancaran aktifitas pertumbuhan dipucuk yang tergantung pada suplai factor tumbuhnya seperti daun yang melakukan proses fotointesis dan menghasilkan karbohidrat [7]. Umur terung yang masih berlanjut diduga faktor penyebab belum signifikannya pengaruh beberapa dosis kompos kulit bawang merah terhadap tinggi tanaman terung. Hasil penelitian ini tidak sejalan dengan hasil penelitian. Walaupun belum berpengaruh nyata tetapi pertumbuhan tinggi tanaman semakin meningkat seiring umur tanaman terung bertambah. Dari tabel dapat dilihat bahwa perlakuan dengan menggunakan kompos kulit bawang merah dosisi $800 \mathrm{gr} /$ polibag menunjukkan tinggi tanaman yang tertinggi dibandingkan perlakuan yang lain.

\section{Efektivitas Pemberian Beberapa Dosis}

Kompos Kulit Bawang Merah terhadap

\section{Jumlah Daun Terung}

Pengamatan jumlah daun tanaman terung dilakukan 5 kali yaitu 21 HST, 28 HST, 35 HST, 42 HST, dan 49 HST. Data hasil pengamatan dianalisis menggunakan uji $\mathrm{F}$ dan untuk mengetahui perbedaan antar perlakuan maka dilakukan uji BNT yang hasilnya sebagaimana tertera pada Tabel 2. Dapat kita lihat pada Tabel 2 bahwa terjadi peningkatan yang signifikan terhadap pertumbuhan jumlah daun pada setiap dosis pupuk kompos kulit bawang merah yang digunakan. Namun, analisis anova menunjukkan tidak ada pengaruh nyata perlakuan terhadap jumlah daun tanaman terung.

Jumlah daun dengan pemberian perlakuan belum memberikan respon terhadap semua umur, diduga pengaruh jumlah daun lebih dominan dipengaruhi oleh faktor genetik dan faktor lingkungan [8]. Faktor pertumbuhan lain seperti belum banyak dan ukuran daun dan batang yang masih bertumbuh sehingga menyebabkan pengaruh kompos belum signifikan. Pemupukan merupakan suatu tindakan memberikan tambahan unsur hara pada tanah baik langsung maupun tak langsung sehingga dapat memberikan nutrisi bagi tanaman. Pertumbuhan dan perkembangan tanaman dipengaruhi oleh ketersediaan unsur hara di dalam tanah. Pupuk organik berasal dari tumbuhan dan atau hewan yang telah mengalami proses rekayasa dan mengandung unsur hara yang dibutuhkan oleh tanaman [9]. Kompos kulit bawang merah merupakan pupuk organik yang memiliki banya kandungan hara lengkap dan diharapkan bisa memberikan peningkatan pertumbuhan terung. Namun, dosis kompos dalam penelitian ini murni budidaya organik tanpa tambahan pupuk lain belum mampu memberikan pengaruh nyata, hal ini diduga 
karena penyerapan pupuk kompos yang belum maksimal di media tanam.

Tabel 2. Rekapitulasi hasil uji BNT Efektivitas Pemberian Beberapa Dosis Kompos Kulit Bawang Merah terhadap jumlah daun tanaman terung

\begin{tabular}{cccccc}
\hline Perlakuan & \multicolumn{5}{c}{ Rata-rata jumlah tanaman (helai) } \\
\cline { 2 - 6 } & 21 HST & 28 HST & 35 HST & 42 HST & 49 HST \\
\hline B0 & 4,80 & 4,80 & 5,04 & 5,80 & 5,80 \\
B1 & 5,80 & 5,80 & 6,20 & 7,20 & 6,80 \\
B2 & 6,00 & 6,00 & 7,20 & 9,00 & 8,80 \\
B3 & 5,40 & 5,40 & 6,40 & 8,60 & 9,80 \\
B4 & 5,20 & 5,40 & 6,00 & 6,80 & 7,80 \\
\hline
\end{tabular}

Keterangan : $\mathrm{B} 0=$ tanpa kompos kulit bawang merah, $\mathrm{B} 1=200 \mathrm{gram} /$ polibag, $\mathrm{B} 2=400 \mathrm{gram} / \mathrm{polibag}$, $\mathrm{B} 3=800 \mathrm{gram} /$ polibag, dan B4=1000 gram/polibag. Angka yang diikuti notasi huruf yang sama menunjukkan berbeda tidak nyata.

\begin{tabular}{|c|c|}
\hline Pemberian & terhadap pertumbuhan tinggi tanaman selada \\
\hline Kompos Kulit Bawang Merah terhadap & pada setiap dosis pupuk kompos kulit bawang \\
\hline Tinggi Tanaman Selada & merah yang digunakan. Analisis anova juga \\
\hline Pengamatan tinggi tanaman selada & menunjukkan tidak ada pengaruh nyata \\
\hline dilakukan 4 kali yaitu 7 HST, 14 HST, 21 & semua perlakuan kompos kulit bawang merah \\
\hline n 28 HST. Data hasil pengamatan d & terhadap tinggi tanaman selada. \\
\hline
\end{tabular}
menggunakan uji $\mathrm{F}$ dan untuk mengetahui perbedaan antar perlakuan maka dilakukan uji BNT yang hasilnya sebagaimana tertera pada Tabel 3. Dapat kita lihat pada Tabel 3 bahwa tidak terjadi peningkatan yang signifikan
Tabel 3. Rekapitulasi hasil uji BNT Efektivitas Pemberian Beberapa Dosis Kompos Kulit Bawang Merah terhadap tinggi tanaman selada

\begin{tabular}{ccccc}
\hline Perlakuan & \multicolumn{4}{c}{ Rata-rata tinggi tanaman $(\mathrm{cm})$} \\
\cline { 2 - 5 } & 7 HST & 14 HST & 21 HST & 28 HST \\
\hline B0 & 2,00 & 4,00 & 4,00 & 4,00 \\
B1 & 3,00 & 7,10 & 7,10 & 8,20 \\
B2 & 4,50 & 5,60 & 5,80 & 9,00 \\
B3 & 2,67 & 5,80 & 7,36 & 7,36 \\
B4 & 2,00 & 3,60 & 4,10 & 4,10 \\
\hline
\end{tabular}

Keterangan: $\mathrm{B} 0=$ tanpa kompos kulit bawang merah, $\mathrm{B} 1=200 \mathrm{gram} /$ polibag, $\mathrm{B} 2=400 \mathrm{gram} / \mathrm{polibag}$, $\mathrm{B} 3=800 \mathrm{gram} /$ polibag, dan B4=1000 gram/polibag. Angka yang diikuti notasi huruf yang sama menunjukkan berbeda tidak nyata.

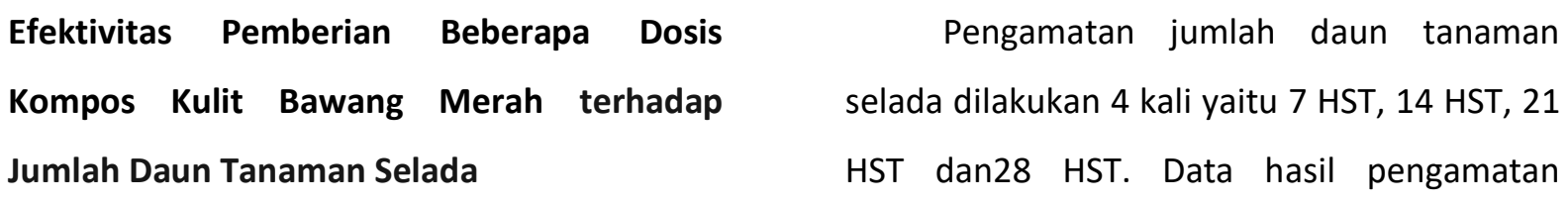


dianalisis menggunakan uji $\mathrm{F}$ dan untuk mengetahui perbedaan antar perlakuan maka dilakukan uji BNT yang hasilnya sebagaimana tertera pada Tabel 4. Dapat kita lihat pada Tabel 4 bahwa tidak terjadi peningkatan yang signifikan terhadap pertumbuhan jumlah daun tanaman selada pada setiap dosis pupuk kompos kulit bawang merah yang digunakan. Analisis anova juga menunjukkan tidak ada pengaruh nyata semua perlakuan kompos kulit bawang merah terhadap jumlah daun tanaman selada pada 7 dan 14 HST namun menunjukkan pengaruh nyata pada 21 dan 28 HST antar perlakuan.

Jumlah daun selada menunjukkan pengaruh nyata saat tanaman sudah mulai besar dan memasuki masa generatif yaitu mulai dari 21 HST hingga 28 HST. Hal ini menunjukkan bahwa pada usia tanaman ini kompos kulit bawang merah belum terurai dan bekerja dengan baik sehingga belum meningkatkan serapan hara tanaman [4].Kandungan unsur hara pupuk kompos kulit bawang merah mengandung belerang yang memberikan kesuburan bagi tanaman sehingga dapat mempercepat tumbuhnya buah dan bunga pada tumbuhan, yang cukup tinggi [10]. Perlakuan kompos kulit bawang merah pada dosis 400 dan 600 gr/polibag menunjukkan jumlah daun yang paling banyak diantara perlakuan lain dan perlakuan kontrol. Unsur hara yang berpengaruh terhadap pertumbuhan dan perkembangan daun adalah Nitrogen (N) [11]. Unsur Nitrogen (N) berfungsi untuk merangsang pertunasan dan penambahan tinggi tanaman, selain itu nitrogen dalam jumlah yang cukup berperan dalam mempercepat pertumbuhan tanaman secara keseluruhan, khususnya batang dan daun. Unsur hara tersebut terkandung dalam kompos kulit bawang merah yang digunakan dalam penelitian.

Tabel 4. Rekapitulasi hasil uji BNT Efektivitas Pemberian Beberapa Dosis Kompos Kulit Bawang Merah terhadap jumlah daun tanaman selada

\begin{tabular}{ccccc}
\hline Perlakuan & \multicolumn{4}{c}{ Jumlah daun tanaman (helai) } \\
\cline { 2 - 5 } & 7 HST & 14 HST & 21 HST & 28 HST \\
\hline B0 & 2,00 & 2,00 & 2,00 & 2,00 \\
B1 & 3,00 & 3,00 & 3,20 & 3,20 \\
B2 & 2,80 & 4,00 & 4,00 & 4,00 \\
B3 & 2,60 & 3,40 & 3,80 & 3,80 \\
B4 & 2,00 & 2,40 & 2,40 & 2,80 \\
\hline
\end{tabular}

Keterangan: $\mathrm{B} 0=$ tanpa kompos kulit bawang merah, $\mathrm{B} 1=200 \mathrm{gram} /$ polibag, $\mathrm{B} 2=400 \mathrm{gram} /$ polibag, $\mathrm{B} 3=800 \mathrm{gram} /$ polibag, dan B4=1000 gram/polibag. Angka yang diikuti notasi huruf yang sama menunjukkan berbeda tidak nyata.

\section{Efektivitas Pemberian Beberapa Dosis \\ Kompos Kulit Bawang Merah terhadap \\ PolikulturTanaman terung dan Selada}

Polikultur merupakan metode dalam pola penanaman lebih dari satu jenis [6]. Berdasarkan pengamatan yang dilakukan 
pada pertumbuhan kedua tanaman tersebut, polikultur keduanya belum memberikan hasil yang maksimal. Hal ini dikarenakan hasil yang diberikan belum berpengaruh nyata terhadap tinggi tanaman dan jumlah daun terung maupun tinggi tanaman selada. Sistem tumpang sari jagung manis ternyata berpengaruh terhadap beberapa variabel pertumbuhan jagung, namun hal ini tidak berlaku dalam polikultur selada dan terung [12].

Syarat tumbuh yang kurang sesuai antara kedua tanaman juga menjadi kendala belum maksimalnya polikultur keduanya. Serapan hara tidak bisa secara keseluruhan diserap oleh kedua tanaman terutama untuk selada, tanaman bahkan terlihat layu pada saat memasuki masa panen dan beberapa menunjukkan fisik yang belum sesuai. Dosis pupuk dan keadaan ternaungi menjadi alasan penting belum baiknya polikultur kedua tanaman tersebut. Tanaman terung memiliki tampilan fisik baik namun tidak untuk selada.

\section{KESIMPULAN}

Dosis kompos kulit bawang merah berpengaruh tidak nyata terhadap pertumbuhan tanaman selada dan terung pada sistem polikultur.

Perlu dilakukan penelitian lebih lanjut tentang penyebab kompos kulit bawang merah tidak mempengaruhi tanaman selada dan terung yang dibudidayakan secara polikultur.

\section{DAFTAR PUSTAKA}

Anonim, 2018. Budidaya Tanaman Sayuran. Direktorat Sayuran dan Tanaman Obat. Direktorat Jenderal Hortikultura. Jakarta.

Anonim, 2017. Teknologi Penggunaan Kompos Bawang Merah Sebagai Campuran Media Tanam dan Media Semai Tanaman Hortikultura di DKI Jakarta. Balai Pengkajian dan Penerapan Teknologi Pertanian. Jakarta.

Dyah, N. 2003. Pemanfaatan Antioksidan Alami Flavonol untuk Mencegah Proses Ketengikan Minyak Kelapa. Laporan Penenaalitian. Jurusan Teknik Kimia FTI UPN Jawa Timur.

Yolanda,S., R. Nurjasmi dan L.S. Banu. 2019. Pengaruh kompos kulit bawang merah dan pupuk NPK terhadap pertumbuhan cabai rawit. Jurnal ilmiah Respati, 10(2): 146-155.

Iswara H.R.A, Mochammad Dawam Maghfoer. 2019. Respons Tanaman Terung (Solanum Melongena L.) pada Sistem Tumpangsari Dengan Selada (Lactuca sativa L.) Akibat Aplikasi Pupuk Kandang Kambing dan EM4. Jurnal Produksi Tanaman, 7 (2).

Anonim, 2019. Pengertian Polikultur, Manfaat dan Contohnya. http://dosenpertanian.com.

Allard. 2001. Pemuliaan Tanaman. Bina Aksara. Jakarta. 
Jurnal IImiah Respati

Hutagalung, O.E.H. 2006. Pengantar Genetika.

Universitas Katolik St. Thomas Sumatera Utara. Medan.

Parnata, A.S. 2010. Meningkatkan Hasil Panen dengan Pupuk Organik. Agromedia Pustaka. Jakarta

Yikwa, P. dan L.S. Banu. 2020. Respon Polikultur Cabai Rawit dan Sawi terhadap Waktu Pengomposan dan Dosis Kompos Kulit Bawang Merah. Jurnal Ilmiah Respati, 11 (1).
Aseptyo FR. 2013. Pemanfaatan Ampas Tebu dan Ampas Teh Sebagai Media Tanam Terhadap Pertumbuhan Tanaman Cabai Merah Keriting (Capsicum annum L.) Ditinjau dari Intensitas Penyiraman Air Teh. Universitas Muhammadiyah Surakarta.

Marliah, A. Jumini, dan Jamilah. 2010. Pengaruh Jarak Tanam Antar Barisan Pada Sistem Tumpangsari Beberapa Varietas Jagung Manis Dengan Kacang Merah terhadap Pertumbuhan dan Hasil. Jurnal Agrista, 14 (1): 30-38. 